Bangladesh J. Plant Taxon. 28(1): 1-10, 2021 (June)

(C) 2021 Bangladesh Association of Plant Taxonomists

https://doi.org/10.3329/bjpt.v28i1.54204

\title{
MOLECULAR EVIDENCE FOR THE STATUS OF BIDENS CONNATA MUHL. EX WILLD. AND B. DECIPIENS WARNST. IN THE OLD AND NEW WORLD
}

\author{
Maria Galkina*, Olga Razumova ${ }^{1}$, Igor Yatsenko², \\ Olga Yatsenko ${ }^{3}$ AND Yulia VinOGRADOVA ${ }^{4}$ \\ Laboratory of Molecular Systematics of Plants, N.V. Tsitsin Main Botanical Garden of \\ Russian Academy of Sciences, Botanicheskaya street, 4, Moscow, Russia
}

Keywords: Bidens connata, B. decipiens, hybrids, ITS 1-2, trnL-trnF, rpl32-trnL.

\begin{abstract}
Earlier, we have established that the European blackjack, which in many literary sources is cited as an invasive North American Bidens connata, was described by Carl Warnstorf back in 1895 as $B$. decipiens and had a hybrid origin (B. frondosa $\times B$. cernua). In this study, we continue to compare the genomes of $B$. connata and $B$. decipiens by molecular genetics and cytological methods. The objects are the $F_{1}$ offsprings of $B$. frondosa, B. connata, and B. cernua collected in 2018 from Minnesota and Wisconsin (USA), grown from seeds in the greenhouse conditions of N.V. Tsitsin Main Botanical Garden of Russian Academy of Sciences, as well as samples of $B$. decipiens, B. frondosa and B. cernua collected from Eastern Europe (Belarus and European Russia). The nucleotide sequences of nuclear (ITS 1-2) and chloroplast (trnL$\operatorname{tr} \mathrm{F}$ and $r p l 32-t r n \mathrm{~L})$ DNA were studied. Analysis of the ITS 1-2 site showed that $B$. connata individuals of North America are not hybrids. Analysis of the chloroplast DNA regions confirmed that both taxa, $B$. connata and $B$. decipiens, are evolutionarily close to B. cernua.
\end{abstract}

\section{Introduction}

Bidens connata Muehl. ex Willd. is a North American species with a natural range from Alaska in the north to Mexico in the south (Strother and Weedon, 2006). At home, this species has high polymorphism, and several of its varieties are described that include B. connata var. ambiversa Fassett, var. anomala Farwell, var. fallax (Warnstorf) Sherff, var. gracilipes Fernald, var. inundata Fernald, var. petiolata (Nuttall) Farwell, var. pinnata S. Watson, var. submutica Fassett (Sherff, 1937, 1962). These varieties differ in color and sculpture of seed wall, and in the shape of leaves and cypselae. In the second half of the XX century, American botanists based on the morphological characters suggested the hybridogenic nature of $B$. connata. They thought that the parental species of B. connata were B. frondosa L. and B. cernua L. (Crowe and Parker, 1981). Bidens decipiens Warnst. was described by Carl Warnstorf in 1895 from the European samples, but later on the plants with a set of similar characteristics were defined by European botanists as

*Corresponding author. E-mail: mawa.galkina@gmail.com

${ }^{1}$ Laboratory of Dendrology, N.V. Tsitsin Main Botanical Garden of Russian Academy of Sciences, Botanicheskaya street, 4, Moscow, Russia

${ }^{2}$ Laboratory of Tropical Plants, N.V. Tsitsin Main Botanical Garden of Russian Academy of Sciences, Botanicheskaya street, 4, Moscow, Russia

${ }^{3}$ Laboratory of Flora, N.V. Tsitsin Main Botanical Garden of Russian Academy of Sciences, Botanicheskaya street, 4, Moscow, Russia

${ }^{4}$ Laboratory of Applied Genomics and Crop Breeding, All-Russia Research Institute of Agricultural Biotechnology, Moscow 127550, Russia. 
"B. connata" and classified as an alien species of North American origin, although significant differences in morphology between European and American individuals were noted (Andreau and Vilà, 2010; Mayorov and Vinogradova, 2013). In current time, B. decipiens is recorded as a synonym of B. connata in The Plant List and POWO databases (Royal Botanic Gardens Kew sources).

The type specimens collected by Carl Warnstorf for the European Herbarium project were sent out as an exiccatae to the herbaria of Edinburgh (E), Frankfurt (FR) and Charles University in Prague (PRC) (Global Plants, 2019). We studied the morphological characters of B. decipiens in Russia previously. We have discovered that characters of that species are transitional between the North American invasive B. frondosa L. and the native B. cernua L. (Galkina et al., 2015), which may indicate a hybrid origin of $B$. decipiens. Thus, the achenes of $B$. decipiens are covered with two types of hairs - duplex, consisting of two cells (as in $B$. frondosa), and simple multicellular (as in B. сеrnua). In addition, the achenes of $B$. decipiens are tetrahedral, have four spines (as in $B$. cernua), and are covered with warts (as in $B$. frondosa). The heads of $B$. decipiens are similar to those of $B$. frondosa in size and shape, and its leaves are entire, as in B. cernua. On the basis of these data, we hypothesized the hybrid origin of $B$. decipiens (Vinogradova and Galkina, 2015).

Our studies of $B$. decipiens samples and its presumed parental species collected in Eastern Europe confirmed the point of view above (Galkina and Vinogradova, 2019). Analysis of the ITS 1-2 and $\operatorname{trn} \mathrm{L}-\operatorname{trn} \mathrm{F}$ nucleotide sequences of European plants made it possible to prove that $B$. decipiens is a hybridogenic taxon, with maternal species $B$. cernua, and the paternal species $B$. frondosa with a high probability (Galkina and Vinogradova, 2019). At the same time, according to the analysis of ISSR fragments, the paternal species ( $B$. frondosa) population itself has a high genetic diversity in the secondary distribution range (Vyšniakienè et al., 2018).

For the Asteraceae family, hybridogenic activity has also been established within other genera, for example, sunflower hybrids Helianthus annuus $\times$ H. tuberosus. In the case of hybrids, the chromosomes of one of the parents (or portions of these chromosomes) may be lost in favor of the chromosomes of the second parent (Kantar et al., 2014).

The possibility of a hybrid origin of $B$. connata in North America requires further study. If this taxon was indeed a hybrid of $B$. frondosa and B. cernua, then it would be impossible to speak unambiguously about the European origin of $B$. decipiens. Also, there would have been an alternative to the introduction of a hybridogenic taxon into Europe. This study aims to compare the genomes of North American B. connata and European B. decipiens by molecular and cytological methods to confirm the non-identity of these taxa.

\section{Materials and Methods}

\section{Plant material}

Seeds of B. frondosa, B. connata and B. cernua were collected during an expedition in October 2018 in the states of Minnesota and Wisconsin (USA) in three locations: vicinity of Rochester, Minnesota Arboretum, and irrigation dam in the Spooner (Table 1). The micromorphological features of achenes were studied using a Keyence VHX 1000 E digital electron microscope. To measure morphometric features, a sample of 50 achenes was taken for each collection point.

Achenes collected in the USA without stratification were sown on October 26, 2018 in a warm greenhouse of the MBG RAS. The obtained seedlings were the main material of our research. For comparative analysis, samples of B. decipiens, B. frondosa, and B. cernua, collected from Eastern Europe (Belarus and the European part of Russia), were also used. 
Table 1. Samples of the studied taxa of Bidens $\mathbf{L}$.

\begin{tabular}{|c|c|c|c|c|c|}
\hline \multirow[t]{2}{*}{ Species } & \multirow{2}{*}{$\begin{array}{l}\text { DNA } \\
\text { sample no. }\end{array}$} & \multicolumn{3}{|c|}{ GB accession no. } & \multirow[t]{2}{*}{ Place and date of collection } \\
\hline & & ITS $1-2$ & rpl32-trnL & $\operatorname{trn} \mathrm{L}-t r n \mathrm{~F}$ & \\
\hline \multirow[t]{11}{*}{ B. frondosa } & fr_A3 & MT126645 & MT265305 & MT150078 & $\begin{array}{l}\text { Seeds from USA, Minnesota, vicinity of } \\
\text { Rochester, 2018. } 44.02 \text { N } 92.47 \mathrm{~W} \text { plants were } \\
\text { grown in the greenhouse (Moscow), } 2019\end{array}$ \\
\hline & fr_A31 & MT126646 & MT265306 & MT150079 & Seeds from USA, Wisconsin, Spooner, 2018 \\
\hline & fr_A32 & MT126647 & MT265307 & MT150080 & $\begin{array}{l}45.84 \mathrm{~N} 91.88 \mathrm{~W} \text { plants were grown in the } \\
\text { greenhouse (Moscow), } 2019\end{array}$ \\
\hline & fr_A11a & MT671434 & MT702807 & MT702814 & \multirow{4}{*}{$\begin{array}{l}\text { Seeds from USA, Wisconsin, Spooner, } 2018 \text {, } \\
\text { Plants were grown in the greenhouse (Moscow), } \\
2020\end{array}$} \\
\hline & fr_A11b & MT671435 & MT702808 & MT702815 & \\
\hline & fr_A $11 \mathrm{c}$ & MT671436 & MT702809 & MT702816 & \\
\hline & fr_A11d & MT671437 & - & - & \\
\hline & fr_5a & MK559780 & MT265308 & MK575581 & \multirow{2}{*}{$\begin{array}{l}\text { Russia, Vladimir oblast, vicinity of Tasinskiy } \\
\text { village, } 2014, \mathrm{~N} 55.567^{\circ} \mathrm{E} 40.172^{\circ}\end{array}$} \\
\hline & fr_5b & MK559781 & MT265309 & MK575582 & \\
\hline & fr_10a & MK559783 & - & MK575584 & Belarus, Dziaržynsk, 2018 \\
\hline & fr_ $10 \mathrm{~b}$ & МK559784 & MT265310 & MK575585 & $\mathrm{N} 53.693^{\circ} \mathrm{E} 27.165^{\circ}$ \\
\hline \multirow[t]{7}{*}{ B. connata } & conA15a & MT671432 & MT702805 & MT702812 & Seeds of plants from Minnesota Arboretum \\
\hline & conA $15 b$ & MT671433 & MT702806 & MT702813 & $\begin{array}{l}\text { Plants were grown in the greenhouse (Moscow), } \\
2020\end{array}$ \\
\hline & con_A2 & MT126648 & MT265311 & MT150081 & $\begin{array}{l}\text { Seeds from USA, Minnesota, vicinity of } \\
\text { Rochester, 2018, } 44.02 \text { N 92.47 W Plants were } \\
\text { grown in the greenhouse (Moscow), } 2019\end{array}$ \\
\hline & con_A2-20 & - & MT702804 & MT702811 & $\begin{array}{l}\text { Seeds from USA, Minnesota, vicinity of } \\
\text { Rochester, 2018, } 44.02 \text { N 92.47 W Plants were } \\
\text { grown in the greenhouse (Moscow), } 2020\end{array}$ \\
\hline & con_A22 & MT126649 & MT265312 & MT150082 & Seeds from USA, Minnesota, vicinity of \\
\hline & con_A23 & MT126650 & MT265313 & MT150083 & Rochester, 2018, 44.02 N 92.47 W \\
\hline & & & & & $\begin{array}{l}\text { Plants were grown in the greenhouse (Moscow), } \\
2019\end{array}$ \\
\hline \multirow[t]{6}{*}{ B. decipiens } & de_la & MК559763 & MT265314 & MK575566 & \multirow{2}{*}{$\begin{array}{l}\text { Russia, Kaluga oblast, Milyatinskoe water } \\
\text { reservoir, } 2013 \\
\mathrm{~N} 54.4914^{\circ} \mathrm{E} 34.3393^{\circ}\end{array}$} \\
\hline & de_lb & MK559764 & MT265315 & MK575567 & \\
\hline & de_4a & MK559774 & MT265316 & MK575575 & \multirow{2}{*}{$\begin{array}{l}\text { Russia, Vladimir oblast, vicinity of Tasinskiy } \\
\text { village, } 2014 \mathrm{~N} 55.567^{\circ} \mathrm{E} 40.172^{\circ}\end{array}$} \\
\hline & de_4b & MK559775 & MT265317 & MK575576 & \\
\hline & de_11a & MK559776 & MT265318 & MK575577 & Belarus, Dziaržynsk, 2018 \\
\hline & de_11b & MK559777 & MT265319 & MK575578 & $\mathrm{N} 53.693^{\circ} \mathrm{E} 27.165^{\circ}$ \\
\hline \multirow[t]{9}{*}{ B. сегnиа } & cer_A1 & MT126651 & MT265320 & MT150084 & \multirow{3}{*}{$\begin{array}{l}\text { Seeds from USA, Minnesota, vicinity of } \\
\text { Rochester, 2018, } 44.02 \mathrm{~N} 92.47 \mathrm{~W} \\
\text { Plants were grown in the greenhouse (Moscow), } \\
2019\end{array}$} \\
\hline & cer_A12 & MT126652 & MT265321 & MT150085 & \\
\hline & & & & & \\
\hline & cer_A14 & - & MT702803 & MT702810 & Seeds of plants from Minnesota Arboretum \\
\hline & & & & & $\begin{array}{l}\text { Plants were grown in the greenhouse (Moscow), } \\
2020\end{array}$ \\
\hline & cer_8a & MK559757 & MT265322 & MK575561 & \multirow{2}{*}{$\begin{array}{l}\text { Russia, Vladimir oblast, vicinity of Tasinskiy } \\
\text { village, } 2014 \mathrm{~N} 55.567^{\circ} \mathrm{E} 40.172^{\circ}\end{array}$} \\
\hline & cer_8b & МК559758 & MT265323 & MK575562 & \\
\hline & cer_9a & МК559760 & MT265324 & MK575563 & Belarus, Dziaržynsk, 2018 \\
\hline & cer_9b & MK559761 & MT265325 & MK575564 & $\mathrm{N} 53.693^{\circ} \mathrm{E} 27.165^{\circ}$ \\
\hline
\end{tabular}




\section{Molecular data}

DNA was extracted from silicagel dried leaves of Bidens taxa following the method of Rogers and Bendich (1985). The herbarium specimens of European plants are stored in the Herbarium of the Tsitsin Main Botanical Garden (MHA). PCR was carried out in a DNA Engine Dyad Peltier Thermal Cycler amplifier (Bio-Rad, United States). For the nuclear ribosomal internal transcribed spacer 1-2 (ITS1-2), nnc18s10 (forward) and c26A (reverse) primers with an annealing temperature of $50^{\circ} \mathrm{C}$ were used. For the chloroplast DNA, primers were used at the annealing temperature from 0.3 to $65^{\circ} \mathrm{C}$ (Shaw et al., 2007). For the chloroplast locus $r p l 32-t r n \mathrm{~L}$ we used primers $r p l 32 \mathrm{~F}$ (forward) and $t r n \mathrm{~L} \mathrm{UAG}$ (reverse). For the chloroplast locus $t r n \mathrm{~L}-t r n \mathrm{~F}$ we used primers $c$ (forward) and $f$ (reverse). Purification of the PCR product for sequencing was carried out in a mixture of ammonium acetate with ethanol. The nucleotide DNA sequences were determined on an automatic sequencer (Syntol).

\section{Analysis of molecular data}

Further processing of the nucleotide sequences was carried out in the BioEdit program. Sequences was aligned using ClustalW than modified manually. ITS1-2 and chloroplast regions were analyzed separately. The data were submitted to GenBank (NCBI, 2020), in which these nucleotide sequences can be found by their accession numbers (Table 1). Phylogenetic tree was constructed in the SplitsTree4 program by neighbor-joining algorithm with bootstrap support. Haplotype networks were constructed using TCS.

\section{Chromosome preparations and analysis of chromosomal data}

For chromosome preparations the actively growing young plants root were used. Approximately $1.5-2.0 \mathrm{~cm}$ long root tips were harvested separately from the plants and immediately pre-treated with a $2 \mathrm{mM}$ aqueous solution of 8-hydroxyquinoline for $4 \mathrm{~h}$ at room temperature (RT) in the dark. A 3:1 ethanol/glacial acetic acid (v/v) mix was used for fixation. Meristems of $2 \mathrm{~mm}$ length were cut from fixed root tips and digested in a $10 \mu \mathrm{l}$ enzyme solution (0.5\% cellulase Onozuka R-10 (Serva, Germany) and 0.5\% pectolyase Y-23 (Seishin Corp., Japan)) in $10 \mathrm{mM}$ citrate buffer $(\mathrm{pH}=4.9)$ for $1 \mathrm{~h}$ at $+37^{\circ} \mathrm{C}$. Suspended cells were used for chromosome preparation as described by Kirov et al. (2014) with some modifications.

An AxioScope A1 fluorescent microscope (Zeiss) with phase contrast was used to observe chromosome preparations. The metaphase plates were photographed with a monochrome AxioCam 503 Mono camera and visualized using ZEN software (Zeiss). In each experiment, at least 20 mitotic metaphase plates from each plant were analyzed.

\section{Results and Discussion}

The morphological diagnostic characteristics of the studied samples are summarized in the Table 2. Analysis of the ITS 1-2 site showed that B. frondosa in the primary range has a rather high polymorphism: all three accessions have substitutions that differentiate them from each other. At the same time, the samples from Wisconsin have a high similarity, though, they have many ambiguous readings of the sequence in several positions ( $\mathrm{Y}-\mathrm{C}$ or $\mathrm{T}, \mathrm{R}-\mathrm{A}$ or $\mathrm{G}, \mathrm{W}-\mathrm{A}$ or $\mathrm{T}, \mathrm{K}-$ $\mathrm{G}$ or $\mathrm{T})$. On the chromatograms obtained from sequencing, such readings appear as double peaks (Fig. 1). This indicates their heterozygous origin and a high polymorphism of $B$. frondosa in its natural range.

American specimens of $B$. connata do not have ambiguous readings of the sequence at all, which does not confirm the possibility of their hybrid origin. Moreover, the European B. decipiens has ambiguous readings in several alignment positions, while the nucleotides of the putative 
parents (B. frondosa and B. сеrnua) in these positions, firstly, differ, and secondly, do not have ambiguous readings, which speak in favor of the hybrid origin of this taxon (Fig. 2, Table 3).

The chromosomes of all studied species were small $(<5 \sim \mu \mathrm{m})$ and similar in morphology. Chromosome numbers were established for some samples. They were diploid and $2 n=48$ for $B$. connata (sample from Rochester), B. frondosa and B. decipiens, and $2 n=24$ for B. cernua.

Haplotype networks were built (Fig. 3) based on the result of the analysis of the nuclear (ITS 1-2) and chloroplast regions ( $r p l 32-t r n \mathrm{~L}$ and $t r n \mathrm{~L}-t r n \mathrm{~F})$ of the DNA of all studied samples.

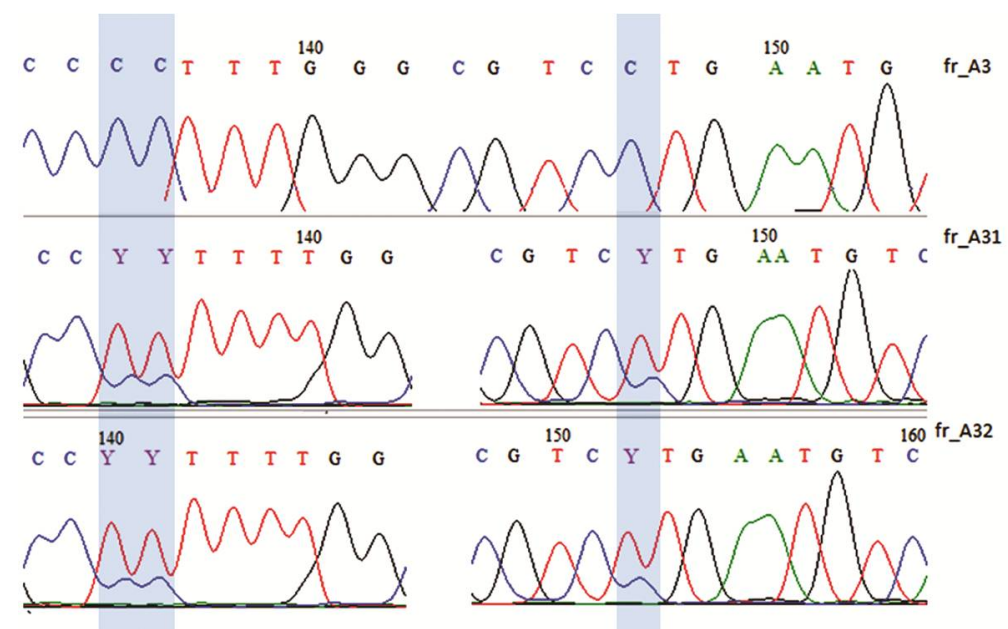

Fig. 1. Fragments of electropherograms of sequences of samples Bidens frondosa from North America.

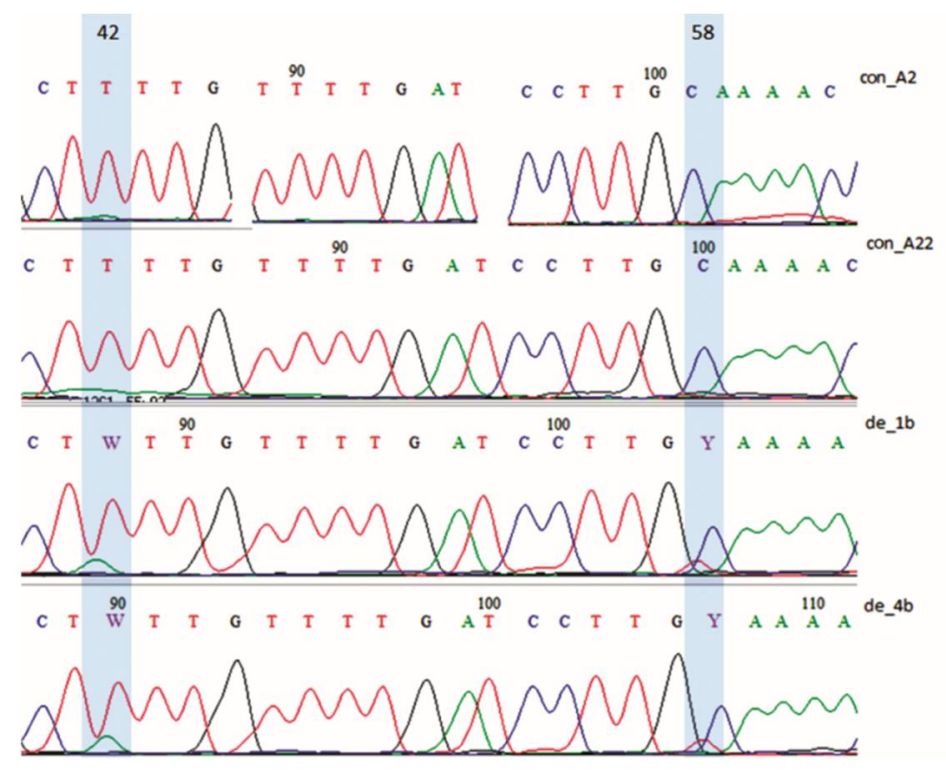

Fig. 2. Fragments of electropherograms of sequences of two samples Bidens connata (from North America) and two samples B. decipiens (from Eastern Europe). "42" and " 58 " - number of nucleotide substitutions in Table 3. 
As for the ITS 1-2 region, the plants in total formed 7 haplotypes. B. frondosa is a very polymorphic taxon, so its all samples were divided into 4 haplotypes, while the common haplotype (№4) included European and American individuals. All B. connata samples were assigned to one haplotype along with the majority of B. сегnua and B. decipiens specimens (№1). The haplotypes №2 and №3 are very close to haplotype №1 and include some individuals of $B$. cernua (cer_8a and cer_8b) and B. decipiens (de_4b).

Table 2. The main diagnostic characteristics of the studied Bidens specimens.

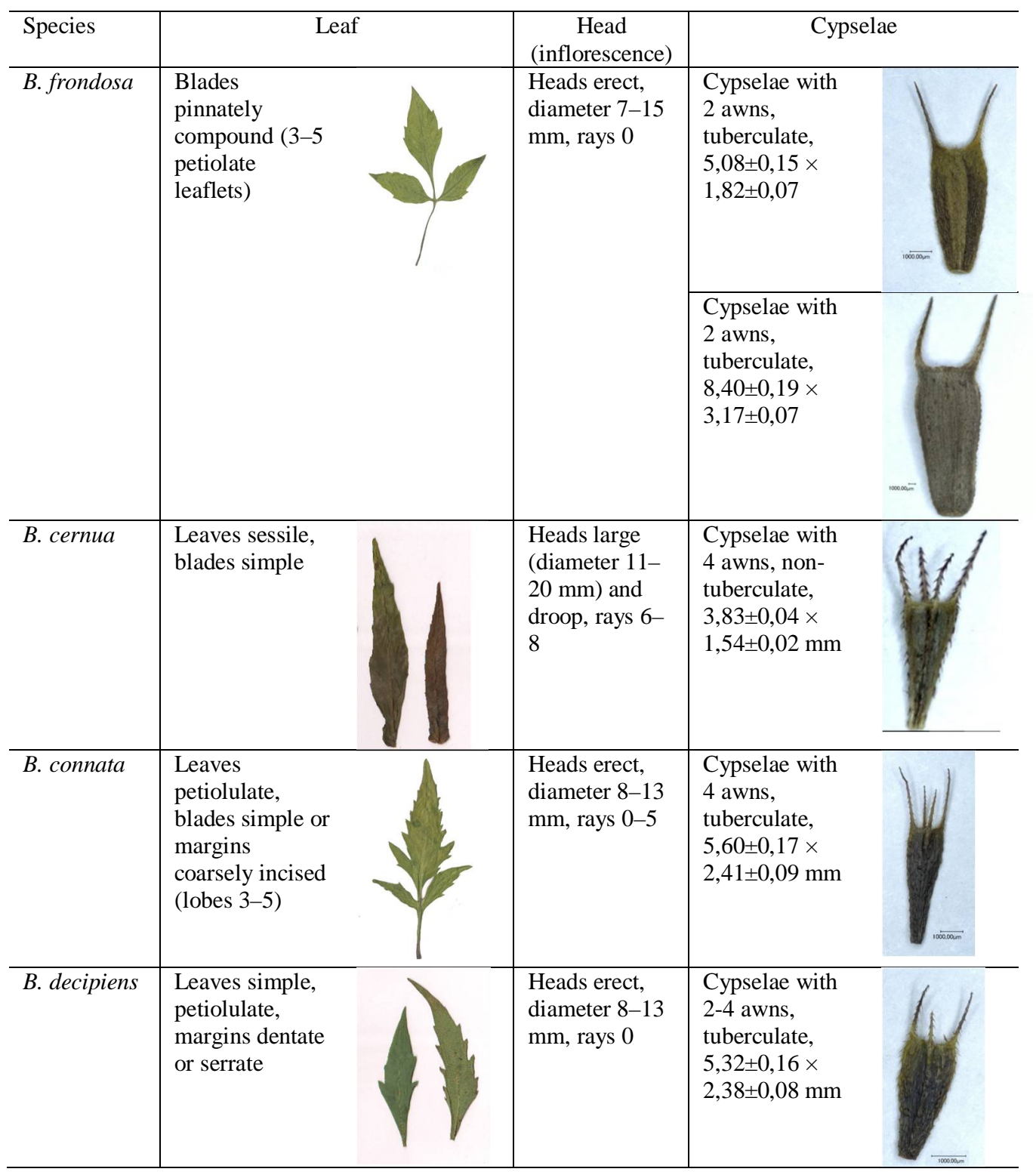


Regarding the chloroplast site, three similar haplotypes (№ 1, 2, and 3) can be distinguished, which included individuals of $B$. cernua and $B$. decipiens, as well as some samples of $B$. connata. Other individuals of $B$. connata (conA_15a, conA_15b, conA_22, conA_23) formed two separate closely related haplotypes (№ 4 and 5) and turned out to be significantly closer to $B$. frondosa than to $B$. cernua and European $B$. decipiens. For example, in the phylogenetic tree constructed using method of the neighbor-joining, all of B. connata samples were divided into two clades - some formed a separate clade (with a bootstrap support of 94\%), while others were placed together with all specimens of B. cernua and B. decipiens with $100 \%$ bootstrap support (Fig. 4). We did not build the tree using algorithms that assume the use of an external group. In this case, it would have been preferable to take as an external group a close species growing both in the Old World and in the New World, which was not possible.

Almost all B. frondosa samples were included in one haplotype, except fr_A3, which formed a separate haplotype also in the analysis of the nuclear region, and also emerged from the general clade in phylogenetic tree based on chloroplast regions (Figs. 3-4).

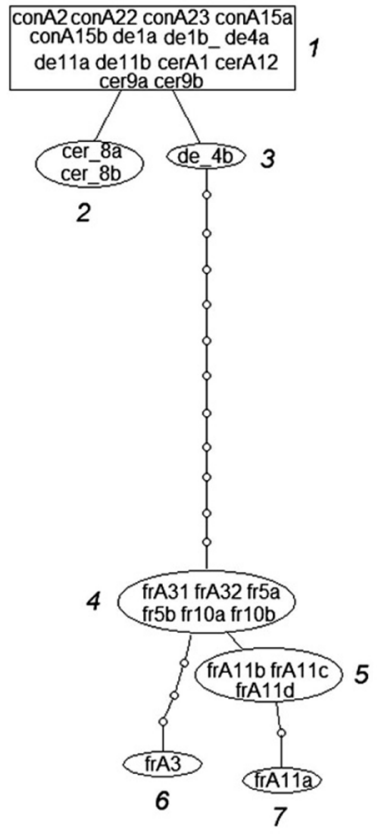

a

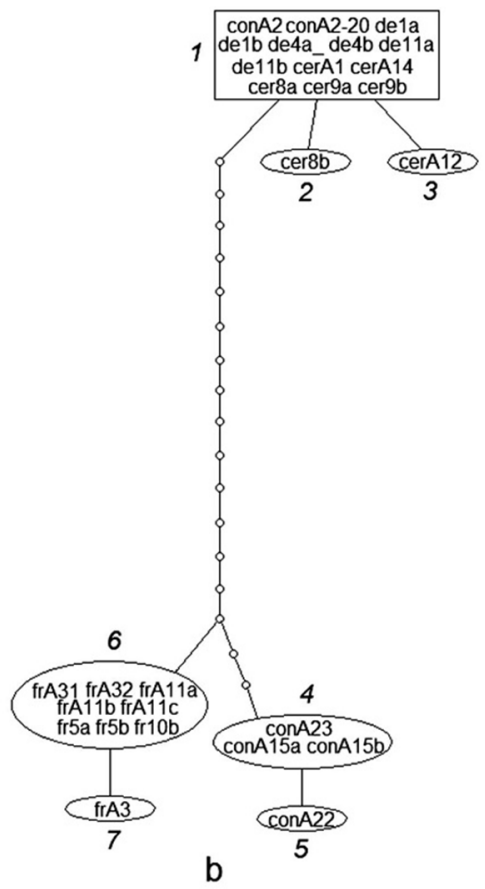

Fig. 3. Haplotype network of different Bidens taxa from North America and Europe, a - ITS 1-2, b chloroplast $(r p l 32-t r n \mathrm{~L}$ and $t r n \mathrm{~L}-t r n \mathrm{~F})$. cer $=B$. cernua, $\mathrm{con}=B$. connata, de $=B$. decipiens, fr $=B$. frondosa.

The individuals of $B$. connata (neither close to B. cernua and European B. decipiens, nor close to $B$. frondosa in chloroplast regions) do not have ambiguous readings of the sequence. And not only in the positions differentiating $B$. frondos $a$ and $B$. cernua, but also in others, as, for example, in some American specimens of $B$. frondosa. Analysis of the ITS region does not even confirm the heterozygous origin of American $B$. connata plants. Therefore we cannot establish their hybrid origin. 


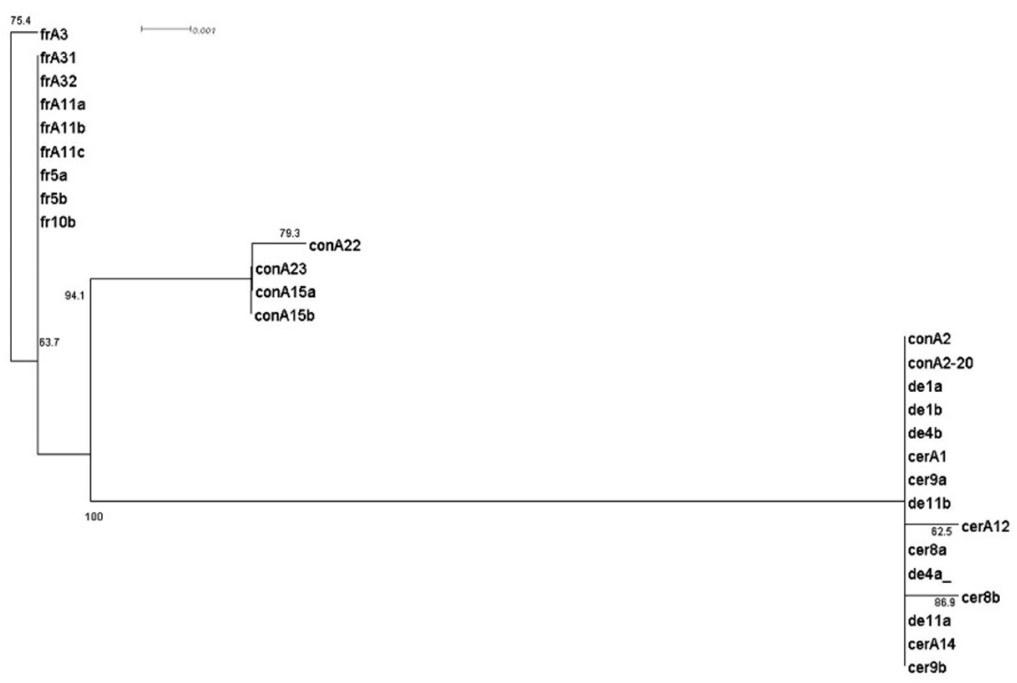

Fig. 4. The Neighbor Joining tree of Bidens taxa from North America and Europe based on $r p l 32-t r n \mathrm{~L}$ and $t r n \mathrm{~L}-t r n \mathrm{~F}$ data. $\mathrm{cer}=B$. cernua, $\mathrm{con}=$ B. connata, $\mathrm{de}=B$. decipiens, $\mathrm{fr}=B$. frondosa .

Table 3. B. connata and B. decipiens and its putative parents polymorphism in the ITS 1-2 sequences.

\begin{tabular}{|c|c|c|c|c|c|c|c|}
\hline \multirow{2}{*}{ Sample № } & \multicolumn{7}{|c|}{ Position in the alignment } \\
\hline & 28 & 42 & 58 & 76 & $90-94$ & 196 & 425 \\
\hline fr_A3 & $\mathrm{C}$ & $\mathrm{T}$ & $\mathrm{T}$ & $\mathrm{T}$ & $\mathrm{CC}$ & $\mathrm{A}$ & $G$ \\
\hline fr_A31 & $\mathrm{C}$ & A & $\mathrm{T}$ & $\mathrm{T}$ & YY & $\mathrm{C}$ & $\mathrm{R}$ \\
\hline fr_A32 & $\mathrm{C}$ & A & $\mathrm{T}$ & $\mathrm{T}$ & YY & $\mathrm{C}$ & $\mathrm{R}$ \\
\hline fr_A11a & $\mathrm{C}$ & A & $\mathrm{T}$ & $\mathrm{T}$ & YY & M & A \\
\hline fr_A11b & $\mathrm{C}$ & A & $\mathrm{T}$ & $\mathrm{T}$ & YY & M & A \\
\hline fr_A11c & $\mathrm{C}$ & A & $\mathrm{T}$ & $\mathrm{T}$ & YY & M & A \\
\hline fr_A $11 \mathrm{~d}$ & $\mathrm{C}$ & A & $\mathrm{T}$ & $\mathrm{T}$ & YY & M & A \\
\hline fr_5a & $\mathrm{C}$ & W & $\mathrm{T}$ & $\mathrm{T}$ & TCTC & M & A \\
\hline fr_5b & $\mathrm{C}$ & W & $\mathrm{T}$ & $\mathrm{T}$ & TCTC & M & A \\
\hline fr_10a & $\mathrm{C}$ & W & $\mathrm{T}$ & $\mathrm{T}$ & TCTC & M & A \\
\hline fr_- $10 \mathrm{~b}$ & $\mathrm{C}$ & W & $\mathrm{T}$ & $\mathrm{T}$ & TCTC & M & A \\
\hline $\operatorname{con} A 15 a$ & $\mathrm{~T}$ & $\mathrm{~T}$ & $\mathrm{C}$ & $\mathrm{C}$ & $\mathrm{C}$ & A & G \\
\hline conA $15 b$ & $\mathrm{~T}$ & $\mathrm{~T}$ & $\mathrm{C}$ & $\mathrm{C}$ & $\mathrm{C}$ & A & G \\
\hline con_A2 & $\mathrm{T}$ & $\mathrm{T}$ & $\mathrm{C}$ & $\mathrm{C}$ & $\mathrm{C}$ & A & $\mathrm{G}$ \\
\hline con_A22 & $\mathrm{T}$ & $\mathrm{T}$ & $\mathrm{C}$ & $\mathrm{C}$ & $\mathrm{C}$ & A & $\mathrm{G}$ \\
\hline con_A23 & $\mathrm{T}$ & $\mathrm{T}$ & $\mathrm{C}$ & $\mathrm{C}$ & $\mathrm{C}$ & A & $\mathrm{G}$ \\
\hline de_ta & $\mathrm{Y}$ & W & $\mathrm{C}$ & $\mathrm{C}$ & $\mathrm{C}$ & M & G \\
\hline de_lb & $\mathrm{Y}$ & W & Y & Y & $\mathrm{C}$ & M & G \\
\hline de_4a & $\mathrm{Y}$ & W & $\mathrm{C}$ & $\mathrm{C}$ & Y & M & G \\
\hline de_ $4 b$ & $\mathrm{Y}$ & W & Y & $\mathrm{Y}$ & $\mathrm{Y}$ & M & G \\
\hline $\mathrm{de}_{-} 11 \mathrm{a}$ & $\mathrm{Y}$ & W & $\mathrm{Y}$ & $\mathrm{C}$ & $\mathrm{Y}$ & A & G \\
\hline de_11b & $\mathrm{Y}$ & W & Y & Y & $\mathrm{Y}$ & M & $\mathrm{R}$ \\
\hline cer_A1 & $\mathrm{T}$ & $\mathrm{T}$ & $\mathrm{C}$ & $\mathrm{C}$ & $\mathrm{C}$ & A & G \\
\hline cer_A12 & $\mathrm{T}$ & $\mathrm{T}$ & $\mathrm{C}$ & $\mathrm{C}$ & $\mathrm{C}$ & A & $\mathrm{G}$ \\
\hline cer_8a & $\mathrm{T}$ & $\mathrm{T}$ & $\mathrm{C}$ & $\mathrm{C}$ & $\mathrm{C}$ & A & G \\
\hline cer_8b & $\mathrm{T}$ & $\mathrm{T}$ & $\mathrm{C}$ & $\mathrm{C}$ & $\mathrm{C}$ & A & G \\
\hline cer_9a & $\mathrm{T}$ & $\mathrm{T}$ & $\mathrm{C}$ & $\mathrm{C}$ & $\mathrm{C}$ & A & G \\
\hline cer_9b & $\mathrm{T}$ & $\mathrm{T}$ & $\mathrm{C}$ & $\mathrm{C}$ & $\mathrm{C}$ & A & G \\
\hline
\end{tabular}


We could assume that $B$. connata could still get to Europe, and then it immediately entered hybridization process with B. cernua, and in almost a century and a half, "pure" B. connata did not remain at all. This hypothesis is supported by the fact that we have established only one of the parents of $B$. decipiens - B. cernua. The other parent being $B$. frondosa is our assumption with a high probability (Galkina and Vinogradova, 2019). But this hypothesis is contradicted by the fact that in some areas in Russia, B. decipiens was found far from roads (both railways and highways), and $B$. frondosa and B. cernua also grow in these habitats. Additionally not a single collection of American B. connata was recorded from Europe either in the 19th or in the 20th century. In our opinion, if this hypothesis was correct, then there would be at least an isolated finding of plants with the features of $B$. connata. Therefore, we still adhere to the points that $B$. decipiens arose in Europe independently, and the hybridogenic nature of its origin is confirmed. Our study concludes that (i) B. decipiens, native to Europe, is of hybrid origin, unlike B. connata, native to North America, (ii) Both $B$. connata and $B$. frondosa show high polymorphism in their natural range in North America, (iii) Chloroplast DNA data support two clades within B. connata, in one of which $B$. decipiens and B. cernua are nested, and (iv) B. connata, B. cernua, and B. decipiens are phylogeneticly close. B. cernua is an older species, and B. connata separated from it in America, most likely, several centuries ago. Later, in the 19th century, B. decipiens $(=B$. frondosa $\times B$. cernua) emerged in Europe independently by hybridogenic way. Since the species is a hybrid, its name can be written as $B . \times$ decipiens.

\section{Acknowledgements}

The studies were carried out within the framework of the State Budget Service of Main Botanical Garden, Russian Academy of Sciences, "Hybridization in plants in nature and culture: fundamental and applied aspects" (no. 19-119012390082-6) with the partial financial support of the Russian Foundation for Basic Research (project no. 19-54-26010). The authors of this article are very grateful to the chief of the Lab of Molecular Systematics of Plants Ivan A. Schanzer for valuable advice and assistance in data interpretation.

\section{References}

Andreau, J. and Vila, M. 2010. Risk analysis of potential invasive plants of Spain. J. Nat. Conserv. 18(1): 34-44.

Crowe, D.R. and Parker, W.H. 1981. Hybridization and agamospermy of Bidens in north-western Ontario. Taxon. 30(4): 749-760.

Galkina, M.A., Vinogradova, Yu.K. and Shantser I.A. 2015. Biological and morphological features and microevolution of invasive species of the genus Bidens L. Izv. Akad. Nauk, Ser. Biol. 4: 382-392.

Galkina, M.A. and Vinogradova, Yu.K. 2019. On the Issue of Hybridogenic Origin of Bidens $\times$ decipiens Warnst. Russian Journal of Biological Invasions 10(4): 315-324.

Global Plants, 2019. Global Plants database on JSTOR. https://plants.jstor.org. Accessed on 27 February 2020.

Kantar, M.B., Betts, K., Michno, J.M., Luby, J.J., Morell, P.L., Hulke, B.S., Stupar, R.M. and Wyse, D.L. 2014. Evaluating an interspecific Helianthus annuus $\times$ Helianthus tuberosus population for use in a perennial sunflower breeding program. Field Crops Research 155: 254 -264.

Kirov, I., Divashuk, M., Van Laere, K., Soloviev, A. and Khrustaleva, L. 2014. An easy "SteamDrop" method for high quality plant chromosome preparation. Molecular Cytogenetics 7(1): 21.

Mayorov, S.R. and Vinogradova, Yu. K. 2013. Formation of secondary distribution range and intraspecific variability of Bidens connata. Proc. 12th Reunion on Ecology and Management of Alien Plant Invasions, September 22-26, 2013, Pirenopolis, 119 pp. 
NCBI, 2020. Nucleotide. The Nucleotide database is a collection of sequences from several sources, including GenBank, RefSeq, TPA and PDB. Genome, gene and transcript sequence data providethe foundation for biomedical research and discovery. https://www.ncbi.nlm.nih.gov/nuccore. Accessed on 30 March 2020.

POWO, 2021. Plants of the World online. Royal Botanic Gardens Kew. https://www.powo.science.kew.org Accessed on 22 May 2021.

Rogers, S.O. and Bendich, A.J. 1985. Extraction of DNA from milligram amounts of fresh, herbarium and mummified plant tissues. Plant Mol. Biol. 5: 69-76.

Shaw, J., Lickey, E.B., Schilling, E.E. and Small, R.L. 2007. Comparison of whole chloroplast genome sequences to choose noncoding regions for phylogenetic studies in Angiosperms: the tortoise and the hare III. Am. J. Bot. 94(3): 275-288.

Sherff, E.E. 1937. The genus Bidens. Publ. Field Mus. Nat. Hist., Bot. Ser. 16: 16-74.

Sherff, E.E. 1962. Further notes on the distribution of Bidens connata vars. pinnata and gracilipes. Rhodora 64(757): 23-28.

Strother, J.L. and Weedon, R.R. 2006. Bidens Linnaeus, in Flora of North America. Oxford, pp. 205-206.

The Plant List, 2021. A working list of all plants species. https://www.theplantlist.org. Accessed on 22 May 2021.

Vinogradova, Yu. K. and Galkina, M.A. 2015. On the possibility of hybrid origin of Bidens connata. Proc. XIII Moscow Phylogeny Meet. "50 Years without K.I. Meier," Moscow, February 2-6, 2015, Moscow, pp. 64-69.

Vyšniakienė, R., Rančelienè, V., Naugžemys, D., Patamsytė, J., Sinkevičienė, Z., Butkuvienė, J. and Žvingila, D. 2018. Genetic diversity of populations of Bidens genera invasive and native species in Lithuania. Zemdirbyste-Agriculture 105(2): 183-190.

(Manuscript received on 14 December, 2020; revised on 18 May, 2021) 